Ssciendo Studia Anglica Posnaniensia 56 (2021): 293-322

doi: 10.2478/stap-2021-0031

\title{
CHARACTERISATION AND THEATRICALITY IN \\ KING LEAR OF THE STEPPES: THE REWRITING OF THE SHAKESPEAREAN CLASSIC
}

\author{
MANEL BELLMUNT-SERRANO*
}

\begin{abstract}
This paper provides an in-depth analysis of the rewriting of King Lear, the Shakespearean classic, as it appears in Ivan Turgenev's novella King Lear of the Steppes, published in 1870. In order to study this case of appropriation in Russian literature, which was received with skepticism by many of his contemporaries and forgotten for a long time, the focus is placed on two fundamental aspects: characterisation and theatricality. These two features connect Turgenev's work with the source text and exemplify how adaptation and appropriation function within target cultural systems. Far from being a mere literary experiment, the appropriation of some of Shakespeare's characters in Turgenev's works and their use as literary archetypes was based on ideological reasons that would influence the evolution of nineteenth-century Russian thought. The present research highlights the importance of processes of rewriting, such as adaptation and appropriation, for the development of target cultural systems and, in order to do so, the perspective of adaptation studies is adopted.
\end{abstract}

Keywords: Turgenev; Shakespeare; King Lear of the Steppes; adaptation studies; comparative literature.

\section{Introduction}

The relationship between Ivan Turgenev and English literature, unlike other great Russian writers, has a long tradition, as certified by some of Patrick Waddington's works - in particular, Turgenev and England (1980) and Turgenev and George Sand (1981) - or Glyn Turton's Turgenev and the Context of the English Literature 1850-1900 (1992). The list of works comparing the literary career of the Russian author and the development of English literature in the nineteenth century is enriched by many other illustrious

* Department of English Studies at University Jaume I; Av. Vicent Sos Baynat, s/n 12071, Castellón, Spain; email: bellmunm@uji.es. 
names such as Richard Freeborn, Royal Gettmann, or Gilbert Phelps. To a great extent, this noteworthy success is a consequence of Turgenev's outstanding literary talent; but, as in many other cases in the history of literature, the contribution of other writers and translators has played a decisive role in shaping the reception of the Russian author in the English-speaking world. In this sense, it is worth emphasizing the importance of Henry James' literary criticism or Constance Garnett's translations of Turgenev's works, which made it possible to access his novels, plays, novellas, and short stories in English soon after they had appeared in Russian.

The very fact that Turgenev considered himself "a citizen of the world" a phrase that would seem a little dated today - and an enlightened member of the gentry, in addition to being the first novelist to be awarded an honorary degree at Oxford in 1879 (Andrew 2008: 8), has contributed to his international fame and to being held in particularly high regard in the Anglo-Saxon literary context.

It should be underscored for the purpose of this research that Ivan Turgenev was indeed a great reader of William Shakespeare and Miguel de Cervantes. This influence is particularly visible in the appropriation of Hamlet and Don Quixote, two of the most important archetypes of Western culture, and their adaptation to the context of Russian literature and philosophy. The adoption of these archetypes was highly influential both during his lifetime and after, as it can be traced in the literary careers of writers such as Anton Chekhov, Boris Pasternak, or Fyodor Dostoevsky; or in film makers such as Grigori Kozintsev. On the one hand, the adaptation of Hamlet to the Russian context led to the evolution of "the superfluous man", a concept of great relevance among the intelligentsia, as it served to highlight the detrimental consequences of their inaction. On the other hand, the archetype of Don Quixote was soon associated with "the new men", the proto-revolutionaries who believed that the country needed a radical change toward modernization. ${ }^{1}$

There is a lesser known consideration in the relationship between Ivan Turgenev and William Shakespeare: the fact that Hamlet was not the only archetype based on the work of the Bard of Avon. King Lear should also be added to the group of Western Turgenevan archetypes made up of Hamlet, Don Quixote, Faust, and King Lear. In the case of the latter, which is of central interest in this paper, Turgenev did not only appropriate the main character, as has been the general assumption regarding this novella for a long time, but the Russian author also built his work King Lear of the Steppes (Stepnoi Korol Lir, 1870) as if it were

For more information on the topic, see Tiffany Ann Conroy Moore's Kozintsev's Shakespeare Films (1973: 25-51), and Chris Thurman's "Hamlet Underground: Revisiting Shakespeare and Dostoevsky" (2018: 79-92). 
a 5-act structure. This is particularly surprising, as Turgenev's favorite form was the 2-act play. This indicates a noticeable correspondence between these two works. In order to understand Turgenev's appropriation of the Shakespearean classic, this paper focusses on two fundamental features present in Turgenev's work: characterization and theatricality. Both features will be analyzed in detail in their corresponding sections.

In order to detail this little studied connection between King Lear and Turgenev's rewriting, the perspective of adaptation studies will be adopted to emphasize the relevance of processes such as adaptation and appropriation for the development of target cultural systems. In doing so, the importance of crosscultural relationships will be highlighted and evidence will be provided of how these rewritings tend to conform to the specific characteristics of the target language and culture.

\section{Theoretical framework}

Adaptation and appropriation, understood here as processes of rewriting, have influenced the development of target national literatures over the centuries and have helped shape the evolution of cultural systems. In fact, "adaptations are so much a part of the Western culture that they appear to affirm Walter Benjamin's insight that "storytelling is always the art of repeating stories"' (Hutcheon 2006: 2). However, even today, adaptations and appropriations are sometimes regarded as secondary, derivative or imitative:

Adaptation as a pale copy of the real thing is an entrenched belief prevalent in
popular press reviews of film adaptations, where the final paragraphs almost always
contain an obligatory return to the inevitable "not as good as the book" conclusion.
Such conclusions are reached for the most part by an imperfect knowledge of both
forms by the critic.
(Cartmell \& Whelehan 2007: 3)

In recent years, the discipline of adaptation studies has consolidated its position in the academic world as a scientific and independent field that stresses the importance of certain processes of rewriting for the development of cultures and artistic traditions. Both adaptations and appropriations play a marked role in the creation, evolution, and shaping of cultural identities and, consequently, deserve thorough analysis. In that light, it is necessary to emphasize the importance of scholars such as Julie Sanders, Deborah Cartmell, Thomas Leitch, Linda Hutcheon, or Laurence Raw for the development of this discipline as an independent field. 
Although this area of research is still associated with the adaptation of literary works to the cinema, today the discipline incorporates different models and theories regarding the adaptation of certain texts (literary, musical, audio-visual, interactive or of any other type) to conform to other media or genres. Currently, adaptation studies as a field of research offers a highly transversal and interdisciplinary perspective, which gathers specialists and academics from different areas in a common purpose. However, from a theoretical point of view, this noteworthy degree of transversality also poses some challenges to adaptation scholars and academics:

The interdisciplinary nature of adaptation studies ensures a certain inclusivity,
offering a dynamic convergence of diverse academic disciplines, from film,
literature, history, languages, creative writing, media, music, drama, performance
art, visual art, and new media; but its inherently fractured nature can also herald
division and competing interest.

(Griggs 2016: 1)

One of these "divisions" is focused on the need to find a common framework, which would adopt a multimodal perspective, thus putting aside a certain historical tendency toward favoring literary or filmic hierarchies. However, to this day, this shared framework has not yet been found. In fact, the lack of even an agreed definition of basic concepts such as adaptation and appropriation (Leitch 2008: 72) or the multiplicity of existing models, which can sometimes be contradictory (Leitch 2012), have held back the state of the question, so that the search for a shared and multimodal theoretical framework continues to be one of the major challenges for scholars in this academic field in the twenty-first century.

The aforementioned multimodal framework would be especially relevant in order to address Turgenev's appropriation of King Lear and analyze in greater detail how this work has influenced other Shakespearean adaptations and appropriations in Russia, both in the field of cinema or Russian literature, among others. Such questions have rarely been addressed because of a general tendency to give special prominence to some genres over others. A more interdisciplinary approach would likely provide a wider perspective on the impact of these rewriting processes in target cultural systems.

Although no definitive definition of the concepts of adaptation and appropriation has been provided, it is of paramount importance to offer an approximation to how these two processes of rewriting are going to be understood herein. As Timothy Corrigan states, "since the beginning of the twenty-first century, adaptation studies and definitions of adaptation have grown more numerous ... now identifying adaptation as one of the most dynamic fields in textual and cultural studies of all sorts" (Corrigan 2017: 31). According to Julie Sanders, the concept of adaptation should be understood as a 
commentary on a source text ... achieved most often by offering a revised point of view from the "original", adding hypothetical motivation, or voicing the silenced and marginalized. Yet adaptation can also constitute a similar attempt to make texts "relevant" or easily comprehensible to new audiences and readerships via the process of proximation and updating.

(Sanders 2006: 18-19)

Similarly, Linda Hutcheon tries to address the question of defining this field of research by focusing on the current polysemic nature of the concept of "adaptation". For this scholar, adaptation

\begin{abstract}
can be defined from three distinct but interrelated perspectives ... [F]irst, seen as a formal entity or product, an adaptation is an announced and extensive transposition of a particular work or works. This "transcoding" can involve a shift of medium (a poem to a film) or genre (an epic to a novel), or a change of frame and therefore context .... Second, as a process of creation, the act of adaptation always involves both (re-interpretation) and then (re-)creation. ... Thirdly, seen from the perspective of its process of reception, adaptation is a form of intertextuality: we experience adaptations (as adaptations) as palimpsests through our memory of other works that resonate through repetition with variation.
\end{abstract}

(Hutcheon 2006: 7-8)

Perhaps one of the most disputed aspects, in Linda Hutcheon's definition and those provided by other scholars, is the extent of this re-interpretation or re-creation. Where is the frontier that separates an adaptation from a reimagining, a remake or simply the appropriation of an idea that is transplanted into a new context? Sanders proposes that the distinction depends on the way they are perceived, whether they belong to the author or the adapter. According to this scholar, appropriation should be understood as

\begin{abstract}
[a] more decisive journey away from the informing source into a wholly new cultural product and domain. This may or may not involve a generic shift, and it may still require the intellectual juxtaposition of (at least) one text against another that we have suggested is central to the reading and spectating experience of adaptations. But the appropriated text or texts are not always as clearly signalled or acknowledged as in the adaptive process.
\end{abstract}

(Sanders 2006: 26)

Similarly to Sanders' definition, Timothy Corrigan considers that appropriations are "transformative adaptations that remove parts of one form or text (or even the whole) from their original context and insert them in a different context that dramatically reshapes their meaning" (Corrigan 2017: 26).

The rewriting of "canonical" texts has reinvigorated debates and discussions about the place and position of these "appropriated" texts, as well as their role in the evolution of subsequent narratives. Adaptation and appropriation enable a dialogue between the source and the target texts. This act of communication 
does not only provide some evidence on the nature of art itself, but also regards it, as Robert Stam suggests, as "an endless process of recycling, transformation and mutation with no clear point of origin" (quoted in Griggs 2016: 7).

In that light, it is worth emphasizing that Ivan Turgenev's King Lear of the Steppes is an excellent example of appropriation, a product of a cross-cultural translation. Although some elements from the Shakespearean text have been adapted and appropriated, the resulting product can only be attributed to the Russian author. As previously stated, it is important to understand that no adaptation or appropriation exists in a vacuum, as there is always a context: a time, a place, a culture or a language, among others (Hutcheon 2006: xvi). When texts are adapted or appropriated, a complex process is initiated, and the resulting product becomes assimilated, hybridized, or manipulated with new themes, symbols, or features that conform to the specific conditions of the target culture. In fact, and this is a powerful idea, the impact of stories and their meaning can radically change (Hutcheon 2006: xvi).

Three other concepts are particularly relevant for the purpose of this paper: authorship, classic, and ideology. Although the idea of "author" continues to be central to Western culture, the work of critics and philosophers such as Michel Foucault, Julia Kristeva, or Roland Barthes have questioned and criticized its privileged position in past decades. Articles such as Foucault's "What is an author?" emphasize the importance of rewriting and retelling stories and suggest the search for a new way of experiencing art (Foucault 1984: 119-120).

In addition to the criticism of authorship emanating from post-structuralism, the concept of classic has also been revisited in recent times. Although a "classic" could be understood as a type of text which survives criticism and the passing of time, generates surprise and is still perceived as fresh and necessary (Mukherjee 2014: 31), these works can motivate the creation of new classics. This is the case of Turgenev's Fathers and Sons - based on the adoption of two literary archetypes such as Hamlet and Don Quixote - or James Joyce's Ulysses in which Homer's work can still be recognized. Perhaps the concept of "classic" appears clearer when related to a certain hierarchy of literary texts - a canon rather than when attributing universal or timeless features to these works. More than ever, the canon is a concept under review:

[T]he Western canon-the corpus of works comprising the "classics" of art and literature, the very summit of cultural achievement and universal, is now being undermined by the combined forces of feminism, multiculturalism, popular culture, and relativistic literary theories that have occupied schools and universities since the $1960 \mathrm{~s} \mathrm{....} \mathrm{[i]t} \mathrm{is} \mathrm{therefore} \mathrm{condemned} \mathrm{as} \mathrm{an} \mathrm{elitist,} \mathrm{patriarchical,} \mathrm{racist,}$ or ethnocentric construction [T] he monuments of the old order are thought to be giving way to new canons, greater cultural diversity, and changing political values. 
Even Harold Bloom, who condemns some of the previous literary movements and defines them as the "Schools of Resentment", does not hesitate to underscore the importance of literary influences and the power of rewriting. According to this critic:

great writing is always rewriting or revisionism and is founded upon a reading that clears space for the self, or that so works as to reopen old works to our fresh sufferings. The originals are not original, but that Emersonian irony yields to the Emersonian pragmatism that the inventor knows how to borrow ... [T] he desire to write greatly is the desire to be elsewhere, in a time and place of one's own, in a originality that must compound with inheritance, with the anxiety of influence.

(Bloom 1994: 11-12)

Although these views seem to be opposed, the reality is that they tend to understand the process of canonization in very similar and idealistic terms: "[i]nsofar as the very idea of a canon implies that certain works are more worthy of imitation and continual exegesis than others, canon formation involves the reproduction of, adaptation of, and familiarity with canonical antecedents, whether literal or figurative, direct or indirect, or within the same genre and medium or not" (Kolbas 2001: 4). Aesthetic value is not enough to guarantee survival and other important factors such as its capacity for "continual re-creation, adaptation, and institutional confirmation" (Kolbas 2001: 63) play a fundamental role. This idea is particularly relevant, as it reinforces the constant struggle for survival and the greater appropriateness of some texts in certain target cultural contexts. For instance, the reproduction of Shakespeare in nineteenthcentury Russia, as will be shown later, was much more pertinent than that of any other Western author because it fulfilled certain ideological purposes that were particularly important at that time and in that place.

As previously stated, no adaptation or appropriation is produced in a vacuum. It is rather the opposite because, as with any process of rewriting, they are deeply influenced by contextual factors: political, social and, as specifically indicated above, ideological. In the field of arts and humanities, ideology has often been understood as the set of beliefs but also the mode of thinking of human groups, which consider certain opinions or attitudes as fundamental or commonsensical. And precisely for that reason, ideologies often imply a certain understanding of the world (van Dijk 1998; Verschueren 1999). When a text is rewritten and conformed to another setting, some ideological elements from the source text remain, but many others are added. From that perspective, the resulting product becomes a type of hybrid text, a "palimpsest" (see Genette 1997 [1982]), not only in linguistic terms, but also ideological, political, and social, among many others. This impregnation cannot be regarded as imitative under any circumstances, as this hybrid is capable of producing new and even deeper meanings. 
Turgenev's King Lear of the Steppes, as an appropriation of the Shakespearean classic and a product of cross-cultural translation, becomes the perfect subject for the study of these processes, as adaptation and appropriation prove themselves highly creative and influential. These examples do not only belong to the target cultural system, but exert great influence on its development, inspire other artists and foster discussion and debate.

\section{Turgenev's King Lear of the Steppes}

Turgenev's King Lear of the Steppes (Stepnoi Korol Lir) was published in 1870 and, although it is today regarded as one of the best and most powerful novellas of his artistic maturity period, the work was received with skepticism by Russian critics. Some of his contemporaries understood this work as a "trivialization or vulgarization of Shakespeare's masterpiece" (Seeley 1991: 287); while other scholars such as Afanasy Fet or Nikolay Strakhov also failed to understand the relevance of this literary text and regarded it only as a parody of the play or a mere philosophical and aesthetic criticism of the masterpiece (Volkov 2018: 5). Goncharov defined it as a caricature of the English classic, although this opinion should not be taken seriously, as both writers were on bad terms at that time. Goncharov saw Turgenev as a competitor, accused him of plagiarism - which was completely unfounded according to their contemporaries - and was jealous of his fame (Schapiro 1978: 169). One way or another, this novella was forgotten and regarded as one of his minor works for almost a century. Only in the 1960s did it raise the interest of scholars again, and critics such as Yury Lotman or Yury D. Levin published studies on Turgenev's work. English literary criticism has also long ignored it, and many essays on the Russian author, published either in the twentieth or twenty-first century, do not mention it at all or devote only a few lines to this work. More recently, I. O. Volkov's research paper "The Shakespearean Text of the Story A Lear of the Steppes" (2018) enables interesting associations to be established between Shakespeare's and Turgenev's works in terms of characterization. In fact, Volkov's research paper provides evidence that Turgenev's novella was actually built upon the Shakespearean text, while it introduced many relevant changes.

From the perspective of the plot, the novella tells the story of Kharlov, a physically strong and gargantuan character who decides to transfer his possessions and properties to his two daughters, Anna (the elder) and Evlampia (the younger). This sudden decision is motivated by two equally powerful reasons, the nightmare of an impending death and pride. Kharlov, as Shakespeare's King Lear, fails to understand that the transfer of his properties also implies renouncing his former privileges, power, and authority. 
Consequently, as in the source text, the main character suffers the consequences of his imprudent decision and is forced to face a process of progressive exclusion until he is finally abandoned in the wilderness, helpless and unprotected. This fate had also been foreseen by Souvenir, the Fool in Turgenev's story, during a formal act at the local court. The dénouement of the story portrays a furious Kharlov who violently destroys his own house and dies as a consequence of the roof collapsing. The narrator of the story finds Kharlov's two daughters again. Rumors suggest that Anna poisoned her husband - Slyotkin - and later became a perfect master of the estate. Evlampia, who renounced all her inheritance rights, became the virgin leader of a Flagellant sect.

Unlike Shakespeare's tragedy, the story is told from the perspective of a young third-person homodiegetic narrator, which is reminiscent of the narratological technique employed in other of his previous works, such as for instance First Love, completed in 1860 . In both cases, the narrator is a very mature person, even an old man (Turgenev himself), who retrospectively evokes through his innocent eyes events that took place many years ago (Seeley 1991: 287). It is through this point of view that the story becomes something radically different to the Shakespearean play: the narration of a frustrated adolescent love (Anna in Turgenev's King Lear) and a philosophical portrait of Russian life. This innocent, frustrated love is mentioned at the beginning of the novella when the narrator describes Anna: "[I]t seemed to me that were Anna Martinovna to love me, or even to care to kiss me with her thin cruel lips, I should simply bound up to the ceiling with delight ... Anna Martinovna secretly excited my imagination... though after all, I was only fifteen then, - and at that age!..." (Turgenev 2017: 24). These words not only suggest that this is indeed an adolescent infatuation but also that it took place a long time ago.

In order to analyze King Lear of the Steppes and understand the paramount relevance of this work in the context of Turgenev's artistic maturity period, the present paper focuses on two fundamental aspects: the characterization of the main roles and its theatricality. However, before starting this analysis, it is worth briefly mentioning the introductory note that precedes the narration of the story:

The conversation turned on Shakespeare, on his types, and how profoundly and truly they were taken from the very heart of humanity. We admired particularly their truth to life, their actuality. Each of us spoke of the Hamlets, the Othellos, the Falstaffs, even the Richard the Thirds and Macbeths - the two last only potentially, it is true, resembling their prototypes - whom he had happened to come across.

'And I, gentlemen,' cried our host, a man well past middle age, 'used to know a King Lear.' 
This foreword written by Turgenev is especially relevant for multiple reasons. The first is that it has an evident influence on how the reader receives the story: what the casual audience is going to find in this narrative shares some analogies with the works of William Shakespeare, in particular with King Lear. Consequently, the Russian author deliberately enables an open dialogue with the classic and wants the reader to be aware of that. Secondly, Turgenev in turn continues with an adaptive tradition also used by Shakespeare. This proves that these processes are both highly creative and innovative, and they have been used by great authors throughout history. And, thirdly, by stating the analogy and creating something new and adapted to the particular and specific circumstances of a Russian setting and a different philosophy of life, Turgenev provides evidence that adaptation and appropriation are capable of producing deeper meanings in a new context.

The last of the analogies between the Russian author and the Bard of Avon deals with the conception of literature itself. As was underscored at the beginning of this work, Turgenev was a great reader of Shakespeare - in fact he translated some parts of Othello and King Lear, although he later destroyed them (Freeborn 1960: 23) - and inherited from him, as he acknowledged more than once, that in his writing he always tried to hold the "mirror / up to nature: to show virtue her own feature, scorn her / own image, and the very age and body of the time his / form and pressure" (Hamlet, 3.2.20-23). In fact, as some researchers have sufficiently attested, Turgenev became a mirror of his age and used the Shakespearean words to define his place in Russian literature. To study his literary legacy implies taking a closer look at the evolution of cultural life in his country during the nineteenth century. As William H. Chamberlin aptly states, "[i]t is unfortunate that translations of his works are not accompanied by some sketch of political, social and intellectual trends in the Russia of his time. For Turgenev, far more than Tolstoy or Dostoevsky, is a mirror of his age" (Chamberlin 1946: 10).

\subsection{Characterisation}

One of the most shocking features of Turgenev's prose, in terms of artistic form, is that his novels, novellas, and short stories seem to recombine the same literary elements, which are continuously rearranged and transformed in order to suit each narrative according to the author's intentions (Freeborn 1960: 47). It is commonly agreed that Turgenev was not particularly inclined to literary experimentation; quite the opposite, his prose was built upon some well-established and solid foundations, which he repeated and reformulated several times. Evidently, one of the most outstanding features of his work is the ability to portray the physical and psychological dimension of his main characters, creating flesh and bone 
protagonists endowed with a deep human complexity. As Richard Peace states, Turgenev's capacity for portrayal was highly influenced by Nikolai Gogol. As his master, he employed the same devices: "descriptive names, characterization through speech habits, extended similes, and the presence of refusing to describe what is actually being described" (Peace 1989: 212). Another relevant characteristic of his prose is its realistic tone, although, from time to time, in the shape of epiphanies or revelations, nature emerges behind highly romantic descriptions, almost pantheistic. His narrative makes use of a peculiar realism splashed with romanticism and naturalism, which serves a literary purpose. This quality in his prose surprisingly links Turgenev with Shakespeare, in whose plays the environment and nature sometimes served to complement human emotions - King Lear or Macbeth being good examples of these:

[The] descriptive passages are not introduced by Turgenev purely 'for effect.' They
are all integral to the story or the demands of characterization, serving to evoke
moods, to 'orchestrate' the feelings and thoughts of his protagonists, to introduce
scenes and to illustrate the psychological state of a person at a particular moment.
(Freeborn 1960: 51)

Consequently, the weather and the landscape play a significant role for both authors, either to show an inner struggle or to reflect the main characters' feelings. In that sense, the environment is employed as an extension of human emotion. However, at other times, nature is also felt as indifferent to human suffering, alien to preoccupations, power ambitions, or fears. In that light, God himself is connected to this idea as well:

\footnotetext{
What then is our life? Although there is no overt pessimism in these questions, the answers that Turgenev is later to give in his novels will be profoundly and bitterly pessimistic. Life will become for him 'a tragic comedy' in which the human will is at the mercy of powers vastly superior to it.
}

(Freeborn 1960: 10)

These words would be perfectly suited to describe some of Shakespeare's greatest tragedies, but in fact refer to Turgenev's later literary production and are especially appropriate for King Lear of the Steppes. In very similar terms, Elizabeth Cheresh Allen refers again to this pessimism connected with the impotence of human life and those forces that govern the cosmos. According to this scholar, in his novels, Turgenev's goal is "the guidance of the reader toward the development of the best possible self, which Turgenev defines as the one most capable of enduring the trials of life with equanimity, of surviving setbacks with dignity and integrity" (Allen 1992: 51). Actually, in the threatening environment of the natural world, Turgenev cannot offer any kind of guidance or help provided by the Providence, but "a faith in redemption, not by the grace of a divine being, but by the rational and creative powers of a human being" (Allen 1992: 4). 
Another of Turgenev's major characteristics, which has been studied but not sufficiently highlighted, is the use of Western archetypes motivated by ideological and ethical reasons. Not only have Hamlet and Don Quixote played a decisive role in his works, but also Faust and King Lear. One of the scholars who has studied the use of these archetypes is Frank Friedeberg Seeley (1991):

\begin{abstract}
From archetypal figures in foreign literatures Turgenev had regularly borrowed a single central characteristic as pivot for a work of his own; from Don Quixote the selfless dedication to this ideal; from Hamlet the crippling introspection; from Werther the self-destructive devotion. So now what he takes over from Lear is the towering pride - and the situation: the father who bestows all he has upon his daughters, thinking to govern them through their affection instead of their dependence, and the nemesis that overtakes his overweening.
\end{abstract}

(Seeley 1991: 287)

Although Seeley's words are accurate, one of the purposes here is to highlight that, in the case of King Lear of the Steppes, not only did Turgenev adopt a characteristic as central for his work, but he reused other characters and elements present in Shakespeare's tragedy in order to conform them to a different setting, ideology and purpose. This use of adaptation and appropriation is connected with the definition of ideology provided in the introductory section, as a set of beliefs and conceptions understood as commonsensical by a human group. As Volkov has perfectly noted, there is a clear correspondence in terms of characters between the Shakespearean text and Turgenev's novella (2018), which reveals a more complex plan than previously assumed:

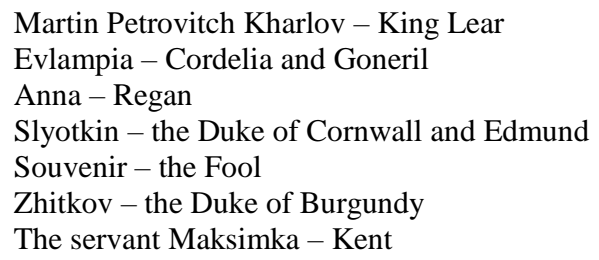

The comparison between these Shakespearean models and their subsequent Turgenevan adaptation to a rural Russian environment unveils many suggestive characteristics of the adaptive process and, at the same time, provides some evidence of the ideological and ethical reasons behind the appropriation of King Lear. Four of these appropriated characters will be analyzed here: Kharlov, Evlampia, Slyotkin, and the Fool. Part of the information provided regarding the characterization of these models was also included in a previous research work, ${ }^{2}$

2 For further information on the topic, please see Manel Bellmunt Serrano's "Turgenev's Appropriation of King Lear: A Case of Medieval Transmission and Adaptation (2019: 59-86). 
although it is expanded here with new findings and examples. Moreover, the analysis of a fourth character (that of Slyotkin) was absent in that previous article and has been added to the present work.

Much has been written about King Lear, his physical appearance and his unspecified number of servants (Bradley 1992 [1904]; Halio 2005; Kahan 2008). In one of his papers, Lionel C. Knights discusses the ambiguity of Lear's physical description and the purpose of this inaccurate portrait:

\begin{abstract}
What do we know of Lear's appearance, or of what the heath looked like? Lear is a powerful man, "four score and upward", and the crown of his head ("this thin helm") is covered by a few white hairs; the heath is a desolate place ... that is all we know of the appearance of either.
\end{abstract}

(Knights 1963: 28-29)

This ambiguity has historically contributed to multiple interpretations of the tragedy - and, to a great extent, to it being regarded as unstageable by most but also to the highly symbolic understanding of the work. In that light, the words of the Fool in Shakespeare's text - "Thou should'st not have been old till thou hadst been wise" (King Lear, 1.5.38-39) - make the readers picture an old and decrepit being, who clearly contrasts with the Turgenevan type, for whom the character is a powerful giant:

Picture to yourself a man of gigantic stature. On his huge carcase was set, a little askew, and without the least trace of a neck, a prodigious head. A perfect haystack of tangled yellowish-grey hair stood up all over it, growing almost down to the bushy eyebrows ... when Harlov spoke, it was as though some one were shouting in a high wind across a wide ravine.

(Turgenev 2017: 8)

Kharlov is not only a Herculean character, but also a proud man, who shows himself unable to accept the terrible consequences of his decisions, even when they have proven themselves to be mistaken. In fact, when compared to Shakespeare's character, Turgenev's Kharlov is disfigured by his profound ignorance and his dream of absolute but innocuous power:

Kharlov is an uncouth Hercules ... He is also a quite extraordinary compound of pride and fantasy ... 'Where in the world is there a power that could thwart my will?' (XIV, 217); 'But the Lord God knows that sooner shall this globe of earth be shattered than I take back my word... or lose heart, or regret what I have done!' (XV, 221). It is noteworthy that this pride is rooted not in realities but in fantasies. Kharlov is not at all proud of his prodigious bodily strength: that is just a gift of God.

(Seeley 1991: 288) 
This relationship between the main character and God should be revisited, as it becomes the source of his tremendous power but also the seed of his weaknesses. In fact, Kharlov has a nightmare about a raven colt, which he interprets as a message from God, and also as a premonition of his own fatal death. This open dialogue between the main protagonist and the divinity raises multiple questions on the nature of spirituality and the origins of religious faith. Based on a revelation, or madness, human beings have always understood that God was speaking to them, sending them a message of salvation or announcing that they were "the chosen ones". Through their main characters both authors seem to portray a reassessment - if not a terrible questioning - of God's existence. In Shakespeare's tragedy, this veiled criticism comes in the form of how to reconcile the existence of a supreme and magnanimous divinity with all the cruelty and injustice present in this world:

\footnotetext{
Repeatedly in the play, characters invoke or cite a variety of deities and metaphysical forces. Repeatedly there's a questioning of the entities that may govern our lives: are they kind, blind or cruel? Insistently, too, the play gives instances of the very kinds of suffering that make people seek some consolatory pattern in events.
}

(Watts 1994: 15-16)

This consolatory pattern in events is precisely what Kharlov seems to see in his premonitory dream, a message from God, and he makes the mistaken decision of dividing his properties without reserving a space for himself:

\footnotetext{
There is, maybe, a higher power at work in this, and you talk of melancholy. I thought to do this, madam, because in my own person, while still in life, I wish to decide in my presence, who is to possess what, and with what I will reward each.
}

(Turgenev 2017: 35-36)

Whether this is God's message or Kharlov's mental illness, the reader is unable to decide; however, the way this relationship between the divinity and human beings is depicted raises many questions on its very nature. Kharlov's physical strength is described as a gift, but also as a mask behind which a fragile identity is hidden. Once the protagonist finds himself helpless and abandoned by his beloved ones, this fragility comes to light. Souvenir, who had foreseen Kharkov's tragic fate, describes the real condition of the once powerful man:

\footnotetext{
'The Swede! The Swede, Harlus!' piped Souvenir, doubling up and holding his sides. 'Mighty founder of the illustrious race of Harlovs, look down on thy descendant! What does he look like? Dost thou recognize him? ... Martin Petrovitch and Souvenir, the poor toady, are equal now. He'll have to live on charity now. They'll toss him the stale and dirty crust, that the dog has sniffed at and refused... And they'll tell him to eat it, too. Ha, ha, ha!'
} 
Souvenir's remark does not only parallel the Fool's words in Shakespeare's King Lear: "I am better than thou art now; I am a Fool, thou art nothing" (1.4.181182), but proves that the King and the Fool are at the same level now, or that, in the end, they have become one and the same.

Enraged by Souvenir's mocking, Kharlov decides to come back home and destroy his own house, a symbol of his former power but also confirmation of his terrible mistake. The destruction of his property also moves Evlampia, who offers to return all her properties to their rightful owner: "'Stop, father; come down. We are in fault; we give everything back to you. Come down! ... 'I give you back my share. I give up everything. Give over, come down, father! Forgive us; forgive me'" (Turgenev 2017: 96). However, forgiveness seems impossible now for the furious father:

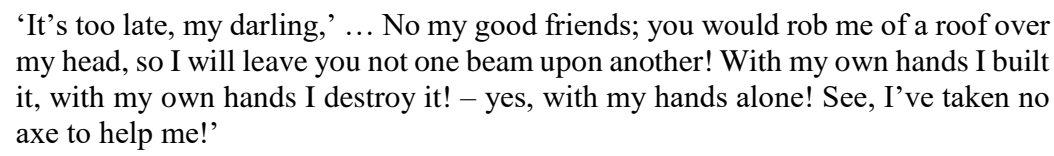
my head, so I will leave you not one beam upon another! With my own hands I built it, with my own hands I destroy it! - yes, with my hands alone! See, I've taken no axe to help me!'

(Turgenev 2017: 96-97)

This unfinished speech leaves the question of forgiveness unanswered “"The end!' ... Well, daugh... ter... you, I do not...” (Turgenev 2017: 101) but the narrator himself prefers to consider that she obtained her father's pardon: "What was it exactly he wanted to say to his daughter? Did he want to forgive her or to curse her? Finally I decided that it was - forgiveness"" (Turgenev 2017: 104). Although the question remains unsolved, compassion is indeed an important word in King Lear of the Steppes and is connected with the interpretation of the main character as a symbolic representation of the country and the political context of the 1870s. It is not by chance that Kharlov is portrayed as a bear at several moments during this work, a symbol which has stereotypically been associated with Russia as a country: savage (uncivilized) but honest. The symbol of the bear holds a special position within the context of Russia as a country and its language. In fact, the word used for "bear" in Russian is medved, which literally means "honey-eater". This word does not derive from old Proto-Indo-European, but it is what linguists define as "substitutes" (Platoff 2012: 100). The reasons for this substitution are not clear, although some religious reasons and others related to some kind of hunter's taboo have been provided to justify it. Another explanation is connected with the bear's capacity to hibernate and come back to life again in the springtime, a quality that Russian people both respected and honored. When assessing the relationship between the animal and the national folklore, the answer is equally uncertain: 
Assessment of the role of the bear in Russian folklore offers scant clarification of the relationship between the Russians and the bear. In traditional folktales, the bear plays a variety of roles, not all of which are particularly flattering. Some tales do ascribe supernatural status to the bear ... More often, however, the bear is portrayed

in less-than-admirable ways in Russian folktales. The animal is often characterized as good-natured, overly trusting, gullible, stupid, lazy, clumsy, and a bit careless with its own strength. Frequently, the bear is exploited or tricked by other animals.

(Platoff 2012: 101)

This description of the bear in Russian folktales is not surprisingly similar to the one provided by Turgenev in his King Lear of the Steppes. Not only does Kharlov display all of the physical and psychological features mentioned above, but also the behavior of the gentry. In fact, Turgenev's story "reveals that the freeing of the serfs, although this was a great boon to the progressive cause, did not necessarily erase the backwards mentality and skewed power relationships entrenched by years of abuse and inequality" (Moore 1973: 112) Kharlov is tricked by his relatives, but his treatment of his servants (and the under-privileged by extension) is described as barely human:

\begin{abstract}
Turgenev made sure that his readers understood that poverty and desperation experienced by the under-privileged and recognized whom to blame for it. Harlov's inability to see the error of his ways, to forgive, or to feel compassion for the poor departs from Shakespeare's development of Lear's character in the service of Turgenev's larger purpose.
\end{abstract}

(Moore 1973: 112)

Thus, there is a fundamental difference between Shakespeare's and Turgenev's King Lear. While, for the former, King Lear was a ridiculous character deserving compassion, Turgenev's is equally naïve, but he does not arouse any compassion, as he is depicted as an unthinking despot: "Regarded as a person, a character, [Shakespeare's] Lear is ridiculous, naïve and stupid. When he goes mad, he can only arouse compassion, never pity or terror" (Kott 1965: 102).

Consequently, it can be inferred that Turgenev envisaged a more complex plan when he decided to appropriate the character of King Lear. The writer adapted Shakespeare's Lear to a Russian environment, not only physically and psychologically, but also from the point of view of his symbolic dimension. Turgenev bestowed upon him features taken from Russian folklore, something that readers would probably perceive as belonging to their cultural identity. This adaptation does not only imply a reworking of the source, but also an ideological and ethical transformation, as the resulting Turgenevan type served a greater purpose: that of creating a symbolical representation of the country and criticizing the backwards mentality and brutality of the upper classes after the "freeing" of the serfs. 
As a Turgenevan model, Evlampia possesses a double nature and could be associated with two characters in Shakespeare's tragedy: Cordelia and Goneril. From the former, Evlampia inherits her coldness and inability to show love to her father properly:

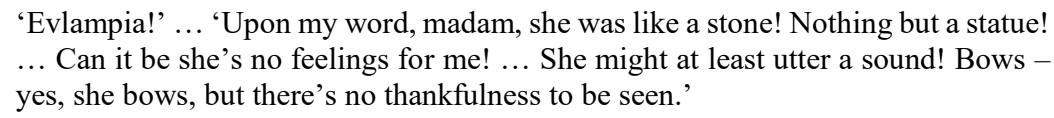

(Turgenev 2017: 52-53)

The similarity between both texts is astonishing, as the younger daughter, the favorite one, fails to show love and respect for her father and is perceived as too cold. However, another startling coincidence emerges when the love contest is analyzed in greater detail. In Shakespeare's tragedy, the nature of this coldness has long intrigued scholars and academics, and made them consider whether King Lear's disappointment was not hiding something else more than fatherly love. As Seeley (1991: 290) has perfectly noted, Turgenev's text also contains a veiled amorous overtone:

'Come, get down; come to me to my little room, to my soft bed. I will dry you and warm you; I will bind up your wounds; see, you have torn your hands. You shall live with me as in Christ's bosom; food shall be sweet to you.'

(Turgenev 2017: 97)

From that perspective, the relationship between Kharlov and Evlampia parallels that of Lear and Cordelia in terms of favoritism and sexual ambiguity, which in both cases would justify the daughters' coldness toward their father.

At the end of the novella, Evlampia becomes the virgin leader of a religious sect and is regarded as "a mother of God" (Turgenev 2017: 111). This connection between the divinity and human beings also connects her to Kharlov: both seem to have been "touched" by God. The extent of this divine contact is ambiguous from any possible interpretation, as no information is provided in that regard, which calls into question the presence of the divinity in this work. Another connection between father, daughter, and God is the feeling of pride present in both characters. This is stated by the narrator when he finds her at the end of the novella. In that light, Evlampia has inherited this quality from her father and, perhaps, the belief that she was in communication with God: "Her face had grown longer and thinner, the skin was darker, here and there lines could be discerned; ... It is difficult to do justice in words to the self-confidence, the sternness, the pride it had gained!" (Turgenev 2017: 112).

However, Cordelia is not the only part played by Evlampia in King Lear of the Steppes. In fact, she can also be linked with Goneril. As in Shakespeare's tragedy, in which both daughters fought for Edmund's favor; in Turgenev's 
novella, the narrator suggests that she is in love with Slyotkin, Anna's husband. One day, the narrator is hunting in the forest and finds Evlampia and her "lover". Although he does not mention it, her song is quite revealing indeed: "Hither, hither, threatening storm-cloud / slay for me the father-in-law / strike for me the mother-in-law / the young wife I will kill myself" (Turgenev 2017: 6768). The same suspicion is later confirmed when Slyotkin tries to prevent Kharlov from destroying the house: "Ah, how d'ye do! My delightful daughter!" Harlov thundered from above. "How d'ye do! Evlampia Martinovna! How are you getting on with your sweetheart? Are your kisses sweet, and your fondling?" (Turgenev 2017: 96).

As previously stated, Slyotkin plays two roles in the novella: that of the Duke of Cornwall - Regan's husband - and that of Edmund. At the beginning of the work, this character is described as an outsider, a foreigner: "I was well acquainted with Harlov's son-in-law. His name was Vladimir Vassilievitch Slëtkin. He was an orphan, brought up by my mother, and the son of a petty official, to whom she had intrusted some business" (Turgenev 2017: 26). However, he is later described as a Jew: "My mother used to call him a little Jew, and certainly, with his curly hair, his black eyes always moist, like damson jam, his hook nose, and wide red mouth, he did suggest the Jewish type" (Turgenev 2017: 26). The use of this antisemitic stereotype, which is reinforced in the last part of the novella - "He had completely gone Jewish, as it is called. He was gasping, threatening, shaking, pointing the gun at Harlov, then letting it drop back on his shoulder" (Turgenev 2017: 94) (the emphasis is mine) - is central to the understanding of the work but it is also ambiguous. As Gary Rosenshield suggests in The Ridiculous Jew (2008), the stereotype of the Jew has played multiple roles in the literary creation of Gogol, Turgenev, and Dostoevsky, among others. In the case of Turgenev, the Jew is used "not for comic relief but as the antihero of an existential drama about death and dying" (Rosenshield 2008: 99). Rosenshield analyzes the use of this typecast in Turgenev's short story "The Jew", but this understanding could be also applied to King Lear of the Steppes. If, as previously stated, Kharlov is a symbolical representation of the country, Slyotkin, a stranger and a foreigner, plays the part of the antihero. Moreover, Turgenev makes use of the antisemitic stereotype to reinforce the moral antithesis between both characters. In that sense, Slyotkin, as Girshel in "The Jew", is "tied to stereotypical Jewish moral defects, the worst being greed (obsession with money) and betrayal" (Rosenshield 2008: 102-103). The use of this antisemitic stereotype should not be understood as some kind of hatred toward the Jewish community. In fact, there are other examples in Turgenev's literary career where this stereotype is reversed, as for instance the short-story "The End of Chertopkhanov". In this story the protagonist saves the life of a Jew who was being beaten by a group of peasants, and the Jew pays him back by 
giving him a horse almost for free, which would change Chertopkhanov's life forever (Rosenshield 2008: 123). Consequently, in King Lear of the Steppes, the use of this stereotype should be understood as a device to underscore Kharlov's symbolical dimension and highlight the ethical and moral turpitude of his antihero. The use of the Jew as a stereotypical image also connects Turgenev with Shakespeare. Although it cannot be said that the Russian author subverted this generalization in King Lear of the Steppes, there are other examples such as "The Jew" and "The End of Chertopkhanov" in which this subversion can be found.

Finally, focus will be placed on Souvenir, the Fool. Both in Shakespeare's and Turgenev's works the Fool plays a highly interesting role as a soothsayer and clown. Souvenir can make people laugh but also predict the future, as he does during the formal act at the local court: "Generous-hearted! Generous-hearted! ... we'll see whether this generosity will be much to his taste when he's stripped naked, the servant of God ... and out in the snow, too!" (Turgenev 2017: 48).

Souvenir's clairvoyance contrasts with Kharlov's short-sightedness. Not only does the Fool see what others cannot, but he also highlights a terrible truth: when Kharlov divided the estate, he also renounced his power and authority. As in Shakespeare's text, the King was no longer a King, but a shadow and a poor fool. However, for Turgenev, the Fool plays an even more important role, as it is his mocking that moves Kharlov to return home and destroy his own property:

\footnotetext{
'Souvenir, Souvenir!' I cried. 'Stop it, I'll tell mamma'.

But Souvenir seemed possessed by frenzy ... 'here we find ourselves, you and I, in the most delicate position. While your daughters, with your son-in-law, Vladimir Vassilievitch, are having a fine laugh at you under your roof. And you should at least curse them, as you promised.'

(Turgenev 2017: 87)
}

As in Shakespeare's tragedy, the opposition King-Fool plays a fundamental role from a philosophical dimension. The Fool unveils that

the philosophy of Clowns is the philosophy that in every epoch shows up as doubtful what has been regarded as most certain; it reveals contradictions inherent in what seems to have been proved by visual experience; it holds up to ridicule what seems obvious common sense, and discovers truth in the absurd.

(Jan Kołakowski, quoted in Kott 1965: 131)

And again, as in Shakespeare's King Lear, the Fool uses mockery to highlight the ridiculousness of Lear and Kharlov's behavior:

Mockery is directed not only at the tormentor, but also at the victim, who believed in the tormentor's justice, raising him to the level of the absolute ... The grotesque 
is a criticism of the absolute in the name of frail human experience. That is why tragedy brings catharsis, while grotesque offers no consolation whatsoever.

(Kott 1965: 104)

However, unlike Shakespeare's character, Kharlov is both a victim and a victimizer. From this point of view, the use of mockery on the part of the Fool produces a twofold effect in Turgenev's novella: the main protagonist is regarded as ridiculous, but unable to arouse any compassion on the part of the reader, as previously discussed. His incomplete speech impedes any possible catharsis of the protagonist. Consequently, forgiveness should also be considered unlikely, and the role of the Fool becomes fundamental in order to disclose this twofold mockery effect. Unlike Shakespeare's Fool, Souvenir's attacks should be regarded as rather personal, even vengeful. The reader is told that Souvenir was the brother of Kharlov's deceased wife, occupied "a position between that of a buffoon and a dependant" and is described as "a pitiful creature, looked down by every one; a toady, in fact" (Turgenev 2017: 18). A few lines later, the narrator adds: "It always seemed to me that had Souvenir had money, he would have turned into the basest person, unprincipled, spiteful, even cruel. Poverty kept him within bounds" (Turgenev 2017: 18). When Kharlov relinquished his former power and became a poor man, his social status and that of Souvenir were equated. This situation "unbounds" Turgenev's Fool and contributes to highlighting the ridiculous portrait of Kharlov while provoking his fateful end. The result is perhaps much more pathetic than in Shakespeare's play.

As previously discussed in this section, the connections between Shakespeare's and Turgenev's versions of King Lear are astonishing and go far beyond the simple appropriation of a central character, plot, or idea. The whole structure of the novella parallels the Shakespearean classic. Not only does it conveniently conform to a Russian environment, but also incorporates many other regional features such as the relationship between masters and peasants, fathers and daughters, local administrative structures or religious sects, among others.

\subsection{Theatricality}

The characterization of the main roles is not the only connection between both versions of the story of King Lear. In fact, Turgenev's King Lear of the Steppes possesses some highly dramatic qualities - also present in some of his other works - which, in this particular case, highlight the relationship between both the source and the target texts.

It is well known that all the plays published during Shakespeare's lifetime did not have act-division of any kind. The 1622 Othello is the only quarto prior to the publishing of the First Folio showing any sort of act-division, although it 
is quite irregular. In addition, this work was not even published during Shakespeare's lifetime, but six years after his death. As for the plays included in the First Folio, twenty-five out of the thirty-six plays are divided into five acts, whereas all the rest are irregularly divided or not divided at all (Snuggs 1960: 52). In that light, Henry L. Snuggs states in his work Shakespeare and Five Acts. Studies in a Dramatic Convention (1960) that

\begin{abstract}
all undivided substantive texts stem directly from an author's manuscript of some variety; all substantive texts showing any sort of act-division, except three, stem from some kind of theatrical manuscript source or from author's foul papers annotated in the theatre or from a quarto used in connection with a theatrical prompt-book.

(Snuggs 1960: 55)
\end{abstract}

Consequently, all evidence suggests that the five-act division, understood here as a systematic textual convention, was adopted after the death of the Bard of Avon. For the purpose of this paper, such questions of Shakespearean textual criticism, although important for any analysis based on his plays, are secondary. The reason for this fact is that Turgenev's interpretation of King Lear - and Shakespeare in general - is basically a question of literary reception in the specific context of Russia. And, although he might have known the textual history of the play, it seems reasonable to think that the five-act version of King Lear is the one Turgenev probably knew.

The history of Shakespeare's literary transmission in Russia is not a trivial issue and should be emphasized in order to understand the relevance of King Lear of the Steppes in the context of the national literature. In fact, the name of the Bard of Avon appeared for the first time in this country in 1748 and any interest in Shakespeare during the eighteenth century went quite unnoticed (Levin 1998: 78). Although some free adaptations of his works are to be found during this initial stage, especially Hamlet, these versions bear little resemblance to the English originals. Even in the first decade of the nineteenth century, the importance of the playwright was barely remarkable. Only in the first decades of the nineteenth century was King Lear first translated into Russian. Although three previous versions in Russian are known - N. I. Gnedich's, V. A. Iakimov's, and V. A. Karatygin's - Aleksander Druzhinin's 1856 version is often regarded as the most relevant (Friedberg 1997: 51). This multiplicity of translations proves that the real revelation of Shakespeare in Russia comes with the emergence of romanticism, especially the German variety:

The special feature of the early-nineteenth century in Russian literature was that its progress depended on the development of liberation ideas in Russian society, and of finding ways to solve the most urgent problems, of which the most pressing was the abolition of serfdom and of social oppression in general.

(Levin 1998: 79) 
As his literary career confirms, Turgenev perfectly embodied these two concerns in the context of Russian literature, and this would explain why archetypes such as King Lear, Hamlet, Faust, or Don Quixote were so useful during his lifetime. However, Turgenev was not alone in this quest. The Decembrist Aleksandr Bestuzhev also stated that copying and imitating Shakespeare was not only a possibility, but a historical need for Russia: "It is not that we ought to imitate Shakespeare; we ought to write in the spirit of our age as Shakespeare did in his" (Levin 1998: 80). The same ideas were constantly repeated over the decades, because Shakespeare became not only a source of inspiration, but also a symbol of the Russian struggle against adversity at different stages of its history. For each and every generation, Shakespeare's works offered a different interpretation, as the film maker Grigori Kozintsev claims: "It is not a question of 'the correct' or 'the erroneous' understanding of Shakespeare, but of the possibility for each artist to find his own meaning in the playwright's art. Theatre audiences will make their own choice. And time will have its say" (Kozintsev 1966: 32).

From that point of view, Turgenev's interpretation of Shakespeare - and King Lear to be more precise - is part of a tradition which began in the eighteenth century and still continues today. However, in order to understand the implications of this act of appropriation, in addition to paying special attention to the characterization of the main roles, it becomes essential to focus on the theatricality of Turgenev's novella. In that light, before analyzing this work, it is necessary to explain how this concept is going to be understood here. To define theatricality is not an easy task, especially after the modern dissolution of the limits between genres. Besides, to determine those features which are specific of the theatrical act, its very nature - if there is one - remains a question open to debate even today. What is theatricality, then? Is it a property that only belongs to the theater, or can we extend it to other genres? Teemu Paavolainen states that

\begin{abstract}
in common parlance, "theatricality" usually comes to connote one of the two things. On the positive side, it is understood as a specific style of theatrical production, intimately related to the rise of the modernist theatre director by the early twentieth century. Ranging from the bodily to the political in orientation (Vsevolod Meyerhold, Bertolt Brecht), the value of such theatricalism has variously been located in the interrelation of different arts forms (Richard Wagner) or in some perceived 'essence' of theatre itself (George Fuchs, Nikolai Evrenov, Peter Brook). On the negative side, and much earlier, theatricality has also been equated with a derived realm of mere appearance, denying access to some allegedly prior, authentic, or essential domain of reality.
\end{abstract}

(Paavolainen 2018: 1)

Michael Polany also defined it as "a concrete idea that one can use directly but that one can only describe indirectly" (quoted in Féral \& Bermingham 2002: 95) 
and, although it has been historically privileged in the context of the theater, according to some scholars such as Josette Féral and Ronald P. Bermingham, theatricality is not strictly a theatrical phenomenon. In fact, this is how this concept is going to be understood here, as a property or quality that goes beyond the theater and implies a highly dynamic process of looking and being looked at. According to the aforementioned scholars (Féral \& Bermingham 2002: 96-97), theatricality depends upon three main features: the space or spatial realization of the text (fundamental for the passage from literary to theatrical); the performer's attitude or the theatrical intention addressed to the spectator; and the observer's perception or a certain "gaze" on the part of the spectator that perceives a certain theatricality in a particular situation. As a result, theatricality is an act of representation, the creation of a fiction in which both the observer and the observed face one another:

\begin{abstract}
Theatricality appears to be more than a property; in fact, we might call it a process that recognizes subject in process; it is a process of looking at or being looked at. It is an act initiated in one of the two possible spaces: either that of the actor or that of the spectator.
\end{abstract}

(Féral \& Bermingham 2002: 98)

This bidirectional nature is especially relevant in the construction of Turgenev's King Lear of the Steppes, since it permits the observer to recognize the existence of the observed, identify himself/herself and reflect on the consequences of this self-identification. Written and conceived as a national representation of Russia and its people, Turgenev's novella King Lear of the Steppes could be understood as a highly theatrical work. This high degree of theatricality present in Turgenev's prose writings is nothing new and has been noted over the years by several authors and scholars such as Richard Freeborn, Frank Friedeberg Seeley, Sang Hyun Kim, or Leonard Schapiro, among others. This effect is produced thanks to the use of several dramatic conventions that should be analyzed in greater detail. However, before drawing attention to the use of these dramatic techniques, it is noteworthy that all his plays were written during a relatively short period of time (1843-1851), A Month in the Country being his most famous drama. The reason for such a condensed and brief timespan is that Turgenev himself believed that his writing was not particularly well-suited for the theatre, as he stated to his brother in a letter in 1872 after the unsuccessful staging of A Month in the Country: "That is why I gave up writing for the stage after 1851: that is not my type of work" (quoted in Schapiro 1978: 83). Another dramatic sketch, Evening in Sorrento, would later appear in 1852, although the previous year seemed to have mentally put an end to his dramatic period. In fact, this experience would be later regarded by some academics as a transitional stage toward the genre of the novel: 
It is not difficult to see that Turgenev's interest in the theater occurred at a transitional period in his development ... So it is hardly very surprising that his plays should be experimental. They may be considered experimental in two senses, as experiments, that is, in the art of writing for the theater and in the more important sense that they illustrate the way in which Turgenev was experimenting with his own talent, searching for a means of expression, exploring new forms.

(Freeborn, qtd. in Kim 2004: 415)

Although it is probably true that the Russian author was not particularly inclined to literary experimentation, it should not be forgotten that Turgenev's interest in the genre of drama continued during his lifetime and, in fact, had a noteworthy influence on his prose. The fact that the Russian writer was still experimenting with dramatical forms in 1870 - the year of publication of King Lear of the Steppes - proves that his interest in drama was not an ephemeral one. However, although A Month in the Country was re-staged in 1879 and became a success, it was probably too late for the Russian author to come back to drama as a genre. Besides, there was no need for him to return to it as he had never fully abandoned it. In fact, it seems much more correct to say that both drama and novel, as genres, nurtured one another.

The previous statement should not be a surprise, since some scholars such as Victoria Beryozkina-Lipina have aptly remarked on the tremendous influence of Shakespeare on later prose writers such as John Donne, Robert Burton, John Earle, Sir Thomas Browne, or Thomas Taherne. According to this scholar, "they all, like Shakespeare's characters, value the exercise of intellect more than plot or conflict" (Beryozkina-Lipina 1998: 115). Similarly, Shakespeare's great tragedies became an extraordinary source of inspiration for Turgenev and King Lear of the Steppes can be regarded as one of the most salient examples of this Turgenevan "dramatic" prose. In fact, rather than transforming the situation present in the source text (a play) into a novella, the Russian author created a hybrid text, in which the use of certain dramatic conventions contributed to create a high degree of theatricality.

One of the most noticeable dramatic conventions used in Turgenev's novella is the presence of certain types of structure or pattern similar to the five-act tragedy, as noted by Frank Friedeberg Seeley:

[King Lear of the Steppes] is structured in the form of a full-scale five-act tragedy. 'Act I' comprises the first nine chapters: this is the 'ravelling' ... 'Act II' consists of chapters X-XV and encompasses the first climax ... 'Act III' - chapters XVIXXI - represents the peripeteia (reversal) ... In the 'fourth act' - chapters XXIIXXVIII - we have the second climax or catastrophe. Finally the dénouement is crowded into the last three chapters ... this contains the judgement of the people (the chorus) on Kharlov and his family and, in the aftermath of his death, the untimely demise of Slëtkin counterpointing the exaltation of Kharlov's daughters: Anna seen as a new Semiramis or Catherine the Great, Evlampiya as an incarnate goddess.

(Seeley 1991: 287-288) 
Although the dramatic qualities of Turgenev's works should be regarded as a common characteristic, this five-act structure present in King Lear of the Steppes is more recurring during his artistic maturity period, especially with regard to the creation of his greatest novels: Rudin (1856), A Nest of Gentry (1859), On the Eve (1860), and Fathers and Sons (1862). Paradoxically, during his "pure" dramatic period, most of his short sketches were normally one or two-act plays, a pattern also found in some of his most important short stories, as in "Hamlet of the Shchigrovsky District" (1849) (Kim 2004: 416).

Apart from the structure of the work, there are other important features which could be interpreted as dramatic techniques or conventions:

\begin{abstract}
He gives each novel a location, a situation, in some cases only a house ... or a region with several different though mutually connected foci of interest .... and such a location or situation serves to unify each novel, both physically and temporally. Indeed, the temporal unity is almost as important as the unity of place or location ... This ... circumscribes the action of the major participants as if they were performers upon a stage. Turgenev lets the reader know all the salient facts about those characters $[\ldots]$ who are integral to each location or situation, to each "place" in the novel, for they almost have the function of stage properties, characters of a particular place, conditioned by it and typical of it, who rarely if ever step out of the special place assigned to them.
\end{abstract}

(Freeborn 1960: 53)

All of these properties are to be found in King Lear of the Steppes. On the one hand, there is the house of the narrator and his mother, Natalia Nikolaeva, which represents the old traditions of respect and obedience toward parents; and, on the other, Kharlov's properties, built upon the principle of power and authority which, once disintegrated, unveils personal ambitions, jealousy, and greed. There are also three other important locations: the local court, where the division solemnly takes places and is interrupted by Souvenir's premonitory words; the feast, where the pact is sealed, but also Kharlov's tragic destiny; and the burial (the chorus), where the judgement of the people acquires special relevance. The use of very few locations underscores that the action is being condensed to the limit, becoming a stage, "an abstract dramaturgical space that the reader or spectator must construct in the imagination by fictionalizing it" (Pavis 1999: 344, quoted in Kim 2004: 418). In that sense, each of these places represents the special features of those who inhabit them, to the extent that they complement the feelings or mood of the characters, anticipate the dénouement of the work or unveil the psychological dimension of that time period. The main protagonists become actors and actresses on a stage, so that everything they say or do seems to obey the dictates of a stage director. Not only are the locations of paramount importance to understand the motivations and aims of the characters, but also to signal the passing of time. Almost no reference to time is to be found 
in the novella, as this is orchestrated by a succession of "scenes", so that nothing really happens in the intervals between these. Action and time become the same thing, to the extent that it is extremely difficult to distinguish one from the other:

\begin{abstract}
Each episode in the action is like one scene upon a stage, neatly set and neatly accomplished; but such rigidity of form is purely an artistic tenet and does not offend against life. The impression created as a result of this method is not that life has been formalized to suit the tastes and design of the author but that life itself seems simply to have imposed its own natural scheme upon the way in which the fiction is presented to us.
\end{abstract}

(Freeborn 1960: 54)

Another quality worth emphasizing, which in fact is not dramatic per se but contributes to understanding the characters as integral to each location and place, is the presence of the portrait. As it is well-known, Turgenev was a master of portraiture so that, rather than describing, he "painted" his characters as an indispensable and indissoluble part of the scenery. Rather than reading his portraits, the reader actually "sees" them. The descriptions, both physical and psychological, are capable of stopping the passing of time, enabling individual attention to be paid to all the compositional elements of the scenery and everything that happens on the stage:

It is of the nature of portraiture that the subject must be seen frozen in a moment of time; since the present contains the sum of the past, his (or her) history should be limned in the face, occasionally a glance or gesture may hold a hint of the future; and this is generally the technique of Turgenev's portraits.

(Seeley 1991: 106)

This technique does not only try to depict human characters, but also nature, which reflects the feelings of the protagonists and, at the same time, shows its indifference and passiveness toward human suffering:

The weather had been disgusting for the last five days. Shooting was not even to be thought of. All things living had hidden themselves; even the sparrows made no sound, and the rooks had long ago disappeared from sight. The wind howled drearily, then whistled spasmodically ... I was standing moodily at my window; and I remember a sudden darkness came on me - a bluish darkness - though the clock only pointed to twelve.

(Turgenev 2017: 76)

And, finally, there is another dramatic convention: "all the subsequent action of the fiction is influenced by this decisive moment of climax and takes the form of a protracted conclusion or epilogue" (Freeborn 1960: 55). In this case, the epilogue describes how the narrator finds the two daughters again: Anna has become a first-rate manager of the estate and - as townspeople say - poisoned Slyotkin; while Evlamplia has become the virgin of a Flagellant sect. 
To sum up, all the dramatic conventions and techniques analyzed herein the pattern of the five-act tragedy, the unity of space and time, the understanding of characters as integral to each location, and the use of the portrait to reinforce this quality, along with the protracted epilogue - contribute to creating a noticeable sense of theatricality. Although this feature had been noted by several scholars in the past, it had generally only been interpreted in literary terms. As in the case of the use of literary archetypes, the use of dramatic conventions also had some ideological implications, which seem to be connected with the creation of a national representation of Russia and its inhabitants. The use of certain dramatic conventions to create a high degree of theatricality, as the concept has been understood here, enables a deeply dynamic act of representation in which both the observer and the observed meet in one place. Thanks to the bidirectional nature of this "gaze", this fictional representation is capable of propelling the observer to identify with what they are observing.

Although it is certainly true that Turgenev essentially used the same elements to compose his narrative writings, it is also relevant to underscore that these were highly influenced by dramatic techniques. This fusion of narrative and dramatic qualities, this hybridized text, undeniably requires some degree of aesthetic experimentation. His dramatic period was not one of transition toward the genre of the novel, but this dramatic "gaze" remained present in his fiction throughout his entire literary career, providing him with the chance to play with a genre that he loved and enjoyed.

\section{Conclusions}

In the section devoted to the theoretical framework, the focus was placed on the importance of processes such as adaptation and appropriation for the development of target cultural systems, while underscoring that the resulting text became a type of hybrid. From the perspective of this paper, this assumption is not a trivial issue, but an essential one in order to understand the creative capacity of these processes and their impact on culture. In the particular case of Turgenev's King Lear of the Steppes this quality is especially remarkable, as the resulting text perfectly embodies this hybrid nature previously discussed. On the one hand, the Russian author appropriated the main characters, not only King Lear, and adapted them to a Russian setting. This act had radical consequences, as the story was significantly transformed to the social, cultural, political, and ideological features of this country. While discussing some of the main themes present in the source text, Turgenev introduced new ones, such as the relationship between landowners and peasants after the freeing of the serfs in Russia, or the religious relationship between God and human beings in the context of this aforementioned 
country. On the other hand, the focus was also placed on the dramatic techniques and conventions used in his prose, which contribute to a rather perceptible quality of theatricality, as also previously noted by some scholars. The result is a fictional act of representation linking the onlooker with the person who is being looked at, which enables a reassessment and a self-identification with the object or character being observed. This use of dramatic techniques in his writing would refute the general assumption that for Turgenev drama was a transitional phase toward the genre of the novel. In fact, for him, both genres seem to have been equally important, to the extent that they nurtured one another throughout his whole literary career and conflated into a form of hybrid text. This is connected with another repeated assumption: that Turgenev's writing was not particularly inclined to literary experimentation. If the previous remark on the hybrid nature of his writing is accepted, then it should be concluded that a certain degree of literary experimentation is needed.

This paper has attempted to shed some light on the nature of the processes of adaptation and appropriation and illustrate the case of King Lear of the Steppes in the context of Russian literature. This novella - forgotten for a long time is certainly one of the most interesting works of his artistic maturity period and is deserving of thorough analysis. While paying attention to the techniques employed in its literary creation - the characterization and its theatricality adaptation and appropriation have been revealed as two devices capable of creating new and deeper meanings in target cultural systems. And, at the same time, they foster discussion and debate, and remind us that (re)telling stories was never a derivative or secondary activity.

\section{REFERENCES}

\section{PRIMARY SOURCES}

Shakespeare, William. 1994. King Lear. Edited by Cedric Watts. Wordsworth Classics. Turgenev, Ivan. 2017. King Lear of the Steppes. Skomlin.

\section{SECONDARY SOURCES}

Andrew, Joe. 2008. Introduction: Turgenev and Russian culture. In Joe Andrew, Derek Offord \& Robert Reid (eds.), Turgenev and Russian culture: Essays to honour Richard Peace, Brill. 7-26. DOI: 10.1163/9789401205863_003

Allen, Elizabeth Cheresh. 1992. Beyond realism. Turgenev's poetics of secular salvation. Stanford University Press. 
Bellmunt-Serrano, Manel. 2019. Turgenev's appropriation of King Lear: A case of medieval transmission and adaptation. Moderna Språk 113(2). 59-86.

Beryozkina-Lipina, Victoria. 1998. Three Shakespearean stories in nineteenth-century Russia In Alexandr Parfenov \& Joseph G. Price (eds.), Russian essays on Shakespeare and his contemporaries, University of Delaware Press. 113-126.

Bloom, Harold. 1994. The Western canon. The books and school of the ages. Harcourt Brace \& Company.

Bradley, Andrew Cecil. 1992 [1904]. Shakespearean tragedy. Lectures on Hamlet, Othello, King Lear, Macbeth. Macmillan Education.

Cartmell, Deborah \& Imelda Whelehan (eds.). 2007. The Cambridge companion to literature on screen. Cambridge University Press. DOI: 10.1017/CCOL0521849624

Chamberlin, William H. 1946. Turgenev: The eternal romantic. The Russian Review 5(2). 10-23. DOI: $10.2307 / 125154$

Corrigan, Timothy. 2017. Defining adaptation. In Thomas Leitch (ed.), The Oxford handboook of adaptation studies, 23-35. Oxford University Press. DOI: 10.1093/oxfordhb/9780199331000.013.1

Dijk, Teun A. van. 1998. Ideology. A multidisciplinary approach. Sage.

Féral, Josette \& Ronald P. Bermingham. 2002. Theatricality: The specificity of theatrical language. SubStance 31(2-3). 94-108. DOI: 10.2307/3685480

Foucault, Michel. 1984. The Foucault reader. Pantheon Books.

Freeborn, Richard. 1960. Turgenev: The novelist's novelist. A study. Oxford University Press.

Friedberg, Maurice. 1997. Literary translation in Russia: A cultural history. Penn State University Press.

Genette, Gérard. 1997 [1982]. Palimpsests. Literature in the second degree. Nebraska University Press.

Griggs, Yvonne. 2016. The Bloomsbury introduction to adaptation studies: Adapting the canon in film, TV, novels and popular culture. Bloomsbury Publishing.

Halio, Jay L. 2005. Introduction. In William Shakespeare, The tragedy of King Lear (ed. by Jay L. Halio), Cambridge University Press. 1-94.

Hutcheon, Linda. 2006. A theory of adaptation. Routledge.

Kahan, Jeffrey. 2008. Introduction. In Jeffrey Kahan (ed.), King Lear. New critical essays, Routledge. 1-103.

Kim, Sang Hyun. 2004. A theatrical interpretation of Turgenev's Gamlet Ščigrovskogo Uezda. Russian Literature 56(4). 413-429. DOI: 10.1016/S0304-3479(04)00080-8

Knights, Lionel Charles. 1963. King Lear as metaphor. In Bernice Slote (ed.), Myth and symbol: Critical approaches and applications, Nebraska University Press. 21-38.

Kolbas, E. Dean. 2001. Critical theory and the literary canon. Westview Press.

Kott, Jan. 1965. Shakespeare our contemporary. Methuen \& Co Ltd.

Kozintsev, Grigori. 1966. Shakespeare: Time and conscience. Hill \& Wang.

Leitch, Thomas. 2008. Adaptation studies at a crossroads. Adaptation 1(1). 63-77. DOI: 10.1093/adaptation/apm005

Leitch, Thomas. 2012. Adaptation and intertextuality, or, what isn't an adaptation, and what does it matter? In Deborah Cartmell (ed.), A companion to literature, film, and adaptation, Blackwell. 85-104. DOI: 10.1002/9781118312032.ch5

Levin, Yury D. 1998. Shakespeare and Russian literature: Nineteenth-century attitudes. In Alexandr Parfenov \& Joseph G. Price (eds.), Russian essays on Shakespeare and his contemporaries, University of Delaware Press. 78-96.

Moore, Tiffany Ann Conroy. 1973. Kozintsev's Shakespeare films: Russian political protest in Hamlet and King Lear. McFarland \& Company Inc.

Mukherjee, Ankhi. 2014. What is a classic? Postcolonial rewriting and invention of the canon. Stanford University Press. 
Paavolainen, Teemu. 2018. Theatricality and performativity: Writings on texture from Plato's cave to urban activism. Palgrave.

Pavis, Patrice. 1999. Dictionary of the theatre: Terms, concepts, and the analysis. University of Toronto Press.

Peace, Richard. 1989. The nineteenth century: The natural school and its aftermath, 1840-55. In Charles A. Moser (ed.), The Cambridge history of Russian literature, Cambridge University Press. 189-247. DOI: 10.1017/CHOL9780521415545.006

Platoff, Anne M. 2012. The "Forward Russia" flag: Examining the changing use of the bear as a symbol of Russia. Raven: A Journal of Vexillology 19. 99-126.

Rosenshield, Gary. 2008. The ridiculous Jew. The exploitation and transformation of a stereotype in Gogol, Turgenev, and Dostoevsky. Stanford University Press.

Sanders, Julie. 2006. Adaptation and appropriation. Routledge.

Seeley, Frank Friedeberg. 1991. Turgenev. A reading of his fiction. Cambridge: Cambridge University Press.

Schapiro, Leonard. 1978. Turgenev: His life and times. Oxford University Press.

Snuggs, Henry L. 1960. Shakespeare and five acts. Studies in a dramatic convention. Vantage Press.

Thurman, Chris. 2018. Hamlet underground: Revisiting Shakespeare and Dostoevsky. Multicultural Shakespeare: Translation, Appropriation and Performance 18(33). 79-92. DOI: $10.18778 / 2083-8530.18 .06$

Turton, Glyn. 1992. Turgenev and the context of English literature 1850-1900. Routledge.

Verschueren, Jef (ed). 1999. Selected papers from the 6th International Pragmatics Conference. Vol. 1: Language and ideology. International Pragmatics Association.

Volkov, Ivan O. 2018. The Shakespeare text of the story A Lear of the Steppes by I. Turgenev: Characters' images. Вестник Томского Государственного Университета 426. 5-13.

Waddington, Patrick. 1980. Turgenev and England. Macmillan.

Waddington, Patrick. 1981. Turgenev and George Sand: An improbable entente. Victoria University Press.

Watts, Cedric. 1994. Introduction. In William Shakespeare. King Lear (edited by Cedric Watts), Wordsworth. 9-21. 